\title{
Evaluation of The Erosive Potential of Soft Drinks
}

Sílvia Helena de Carvalho Sales-Peresa, DDS, MS, PHD

Ana Carolina Magalhães ${ }^{b}$, DDS, MS

Maria Aparecida de Andrade Moreira Machadob ${ }^{b}$ DD, MS, PhD

Marília Afonso Rabelo Buzalafa, DDS, MS, PhD

\section{ABSTRACT}

Objectives: This in vitro study evaluated the capability of different soft drinks (Coca-Cola ${ }^{\circledR}-\mathrm{C}, \mathrm{Coca}-$ Cola Light ${ }^{\circledR}-C L$, Guaraná ${ }^{\circledR}-G$, Pepsi Twist ${ }^{\circledR}-\mathrm{P}$ and Sprite Light $^{\circledR}-\mathrm{SL}$ ) to erode dental enamel, relating the percentage of superficial microhardness change (\%SMHC) to concentrations of fluoride and phosphate, buffering capacity and $\mathrm{pH}$ of these drinks.

Methods: The soft drinks were evaluated in respect to concentration of phosphate and fluoride spectrophotometrically using Fiske, Subarrow method and by specific electrode (Orion 9609), respectively. The $\mathrm{pH}$ and the buffering capacity were determined by glass electrode and by estimating of the volume of $\mathrm{NaOH}$ necessary to change the $\mathrm{pH}$ of the drink in one unit, respectively. One hundred specimens of bovine enamel were randomly assigned to 5 groups of 20 each. They were exposed to 4 cycles of demineralisation in the beverage and remineralisation in artificial saliva. The softening of enamel was evaluated by $\% \mathrm{SMHC}$.

Results: The mean $\%$ SMHC was: $\mathrm{C}=77.27 \%, \mathrm{CL}=72.45 \%, \mathrm{SL}=78.43 \%, \mathrm{G}=66.65 \%$ and $\mathrm{P}=67.95 \%$. Comparing the \%SMHC promoted by 5 soft drinks, $S L=C>C L>P=G(P<.05)$. There was not significant correlation between \%SMHC and the other variables tested for the five drinks ( $P>$.05).

Conclusions: The five soft drinks caused surface softening of enamel (erosion). In respect to the chemical variables tested, despite not statistically significant, the $\mathrm{pH}$ seems to have more influence on the erosive potential of these drinks. (Eur J Dent 2007;1:10-13)

Key words: Tooth erosion; Carbonated beverages; Dental enamel.

\section{INTRODUCTION}

Dental erosion is a relatively new risk factor for dental health, introduced by today's lifestyle. This dental lesion is defined as loss of tooth substance by chemical processes not involving bacteria caused by a variety of extrinsic and intrinsic factors. ${ }^{1}$ Demineralisation of tooth by erosion is caused by frequent contact between the tooth surface and acids. Extrinsic factors are related to

$\square$ a Departments of Biological Sciences and Paediatric Dentistry,

b Orthodontics and Public Health, Bauru Dental School, University of São Paulo, Brazil.

$\square$ Corresponding author: Dr. Marília Afonso Rabelo Buzalaf Al. Octávio Pinheiro Brisolla, 9-75 Bauru-SP 17012-901 Brazil.

Tel: + $55143235-8346$

Fax: + $55143227-1486$

E-mail: mbuzalafafob.usp.br

frequent consumption of acidic foodstuffs or beverages and exposure to acidic contaminants in the working environment. ${ }^{2}$ In modern societies the extrinsic factor is becoming more important, due to the increased consumption of acid drinks as soft drinks, sport drinks, fruit juices and fruit teas. ${ }^{3}$

Clinical observation suggests that the length of time the teeth are bathed in the acidic environment is more crucial to erosion than the volume of beverage consumed. It is known that carbonated drinks are frequently held in the mouth until all the bubbles have dissipated. Hence contact time of carbonated drinks with the teeth can be much longer than for non-carbonated beverages. ${ }^{4-6}$

Furthermore, the total acid level, acid type, concentration of phosphate, calcium and fluoride in the drinks have a modifying effect on the development of erosion induced by dietary compo- 
nents. ${ }^{7-9}$

Thus, the aim of this in vitro study was to evaluate the erosive potential of five soft drinks, relating the surface softening of enamel to concentrations of fluoride and phosphate, buffering capacity and $\mathrm{pH}$ of these drinks.

\section{MATERIALS AND METHODS}

\section{Chemical analysis of soft drinks}

Five soft drinks commonly available in the Brazilian market were chosen for this study (CocaCola $^{\circledR}$, Coca-Cola Light ${ }^{\circledR}$, Pepsi Twist $^{\circledR}$, Guaraná Kuat ${ }^{\circledR}$, Sprite Light ${ }^{\circledR}$ J. Each drink was evaluated with respect to its concentration of ions of dental interest. Phosphate was analyzed colourimetrically using Fiske, Subarrow method ${ }^{10}$ (Cary 50, Pharmacia Biotech, Cambridge, England). Fluoride was analyzed by a specific electrode (Orion 9609), after buffering the samples with an equal volume of TI$\mathrm{SAB}$ II. The $\mathrm{pH}$ was determined by glass electrode immediately after opening the bottle. The buffering capacity was determined by monitoring $\mathrm{pH}$, after serial additions of $0.025 \mathrm{~mL} 0.2 \mathrm{~mol} / \mathrm{L} \mathrm{NaOH}$ in $3 \mathrm{~mL}$ of each drink. For comparative purposes, the volume of $\mathrm{NaOH}$ necessary to change the $\mathrm{pH}$ of the each drink in one unit was calculated.

\section{Cycles of de-remineralisation}

Enamel blocks ( $4 \times 4 \times 3 \mathrm{~mm}$ ) were prepared from recently extracted and sound bovine incisors sterilized by storage in $2 \%$ formaldehyde solution (pH 7.0) for 30 days at room temperature. Enamel surface of the blocks was ground flat with water-cooled carborundum discs 1320,600 and 1200 grades of $\mathrm{Al}_{2} \mathrm{O}_{3}$ papers; Buehler, Lake Bluff, IL, USA), and polished with felt papers wet with diamond spray (1 $\mu \mathrm{m}$; Buehler) for surface microhardness determination (five indentations in different regions of the blocks, 25 g, 5 s, HMV-2000; Shimadzu Corporation, Tokyo, Japan).

One hundred blocks with a mean surface microhardness between 335 and 380 Knoop Hardness Number (KHN), were randomly divided into 5 groups corresponding to each soft drink. In the first 24 hours, the blocks were immersed in artificial saliva. After that, they were subjected to four cycles of demineralisation and remineralisation.
One complete cycle comprised the following steps: (1) Demineralisation in $15 \mathrm{~mL}$ of the drink for 10 min. under gentle agitation at $37^{\circ} \mathrm{C}$; (2) remineralisation in $30 \mathrm{~mL}$ of artificial saliva for $60 \mathrm{~min}$. under gentle agitation at $37^{\circ} \mathrm{C}$. After each treatment, specimens were rinsed under deionized water.

Analysis of enamel surface microhardness

The enamel surface microhardness was measured as described earlier and an average per group was obtained. Ten indentations on each specimen were made at a distance of $100 \mu \mathrm{m}$ each, five initially on sound enamel surface (SMH) and five after the demineralisation/remineralisation cycles (SMH1). Using these measurements, the percentage of superficial microhardness change (\%SMHC) was calculated (\%SMHC=[[SMH1-SMH]/ $\left.\mathrm{SMH}{ }^{*} 100\right)$.

\section{Statistical analysis}

The assumptions of equality of variances and normal distribution of errors were checked for all the variables tested. Since the assumptions were satisfied, ANOVA and Tukey's post hoc tests were carried out for statistical comparisons among $\%$ SMHC caused by the drinks. The correlations among \%SMHC and the variables such as $\mathrm{pH}$, buffering capacity, phosphate and fluoride content in drinks were analyzed using Pearson's correlation coefficient. The significance level was set at $5 \%$.

\section{RESULTS}

Table 1 shows the concentrations of fluoride and phosphate, as well as the buffering capacity and $\mathrm{pH}$ of all drinks. Table 2 describes the initial and final $\mathrm{SMH}$ and the $\% \mathrm{SMHC}$ of all drinks: $\mathrm{C}=77.27 \%, \mathrm{CL}=72.45 \%, \mathrm{SL}=78.43 \%, \mathrm{G}=66.65 \%$ and $\mathrm{P}=67.95 \%$. Comparing the $\% \mathrm{SMHC}$ promoted by 5 soft drinks, $(S L=C>C L>P=G)(P<.05)$.

Pearson's correlation coefficient was applied to all beverages, correlating the \%SMHC to the variables evaluated (Table 3). There was no correlation among \%SMHC and chemical variables of the five drinks. Despite a negative correlation was found between the \%SMHC and $\mathrm{pH}(\mathrm{r}=-0.819)$, it was not statistically significant $(P=.09)$.

Table 1. Mean (SD) phosphate and fluoride concentrations, buffering capacity and baseline $\mathrm{pH}$ of the soft drinks analyzed.

\begin{tabular}{lcccc}
\hline Drinks & $\begin{array}{c}\text { Phosphate } \\
\mathrm{mmol} / \mathrm{L}\end{array}$ & $\begin{array}{c}\text { Fluoride } \\
\mathrm{mg} / \mathrm{L}\end{array}$ & $\begin{array}{c}\text { Buffering Capacity } \\
\mathrm{mL} \mathrm{NaOH}\end{array}$ & $\begin{array}{c}\text { Baseline } \\
\mathrm{pH}\end{array}$ \\
\hline Coca-Cola $^{\circledR}$ & $16.781(0.012)$ & $0.322(0.014)$ & $0.100(0.010)$ & $2.9(0.1)$ \\
Coca-Cola Light $^{\circledR}$ & $16.190(0.012)$ & $0.550(0.012)$ & $0.075(0.005)$ & $3.2(0.0)$ \\
Sprite Light $^{\circledR}$ & $0.225(0.015)$ & $0.561(0.014)$ & $0.375(0.011)$ & $3.6(0.1)$ \\
Pepsi Twist $^{\circledR}$ & $3.837(0.035)$ & $0.077(0.002)$ & $0.275(0.021)$ & $3.5(0.1)$ \\
Guaraná Kuat & $0.086(0.016)$ & $0.078(0.005)$ & $0.175(0.009)$ & $3.2(0.1)$ \\
\hline
\end{tabular}




\section{DISCUSSION}

The Sprite Light ${ }^{\circledR}$ and Coca-Cola ${ }^{\circledR}$, that showed the highest buffering capacity and the lowest $\mathrm{pH}$ respectively, had the most pronounced erosive effect on bovine enamel. In agreement, Larsen and Nyvad ${ }^{11}$ state that the potential of a soft drink to erode dental enamel depends not only on the $\mathrm{pH}$, but also on its buffering capacity that is the ability of the drink to resist a change of $\mathrm{pH}$ (to maintain its $\mathrm{pH}$ ). The higher the buffering capacity of a drink, the higher its erosive effect. The fact that Sprite Light ${ }^{\circledR}$, even presenting a higher $\mathrm{pH}$ (3.6), had a similar effect on \%SMHC when compared to Coca-Cola ${ }^{\circledR}(\mathrm{pH}=2.9)$, is probably due to its higher buffering capacity. These variables may be influenced by the concentrations of different ions, such as phosphate, fluoride and calcium. Despite Sprite Light $^{\circledR}$ has a higher fluoride concentration, but a lower phosphate concentration than Coca-Cola ${ }^{\circledR}$, this study was not able to compare the drinks in respect to the concentrations of these ions, because only one sample of each beverage was analysed.

The presence of different types of acids also may help to explain the difference in $\mathrm{pH}$ and buffering effect, since Coca-Cola ${ }^{\circledR}$ and Sprite Light ${ }^{\circledR}$ have phosphoric and citric acids, respectively, according to information obtained from manufacturers. The effect of the type of acid and the amount of ionized acids on mineral dissolution had been demonstrated earlier. ${ }^{12}$ The literature is contradictory regarding the erosive potential of beverages containing citric acid or phosphoric acid. Some studies have shown that beverages containing citric acid are more erosive than those containing phosphoric acid, ${ }^{13-15}$ while others have shown the opposite. ${ }^{16,17}$

However, in the present study a significant correlation was not observed between the \%SMHC and buffering capacity of the drinks. In fact, a negative correlation was found between the \%SMHC and the $\mathrm{pH}$, but this difference was not statistically significant.

The concentration of phosphate in the drinks was low, except for the cola drinks, due to the presence of phosphoric acid, and did not affect the $\% \mathrm{SMHC}$. The rather low concentrations of fluoride in the drinks did not affect the \%SMHC. Sprite Light ${ }^{\circledR}$, which had the highest fluoride concentration, had also the highest \% SMHC.

In the literature, the effect of fluoride on dental erosion has been studied under various conditions with conflicting results. ${ }^{14,18-21}$ It is possible that the increase in the concentrations of fluoride in acid drinks could contribute to reduce their erosive potential. However, a recent review paper showed that fluoride admixtures to acidic solutions in a concentration excluding toxicological side effects seem unable to arrest erosive lesions. ${ }^{22}$ However, other studies have shown that beverage modification by addition of calcium is efficient in preventing erosion. ${ }^{23,24}$

Of special interest is Guaraná, a typical Brazilian carbonated soft drink. The extract of Guaraná is obtained from the dried seeds of Amazonian liana Paullinia cupana (Sapindaceae) and has a wide reputation as a stimulant beverage or nutritional supplement in conditions such as physical and intellectual stress. ${ }^{25-28}$ In the present study, Guaraná had the lowest erosive potential. The variables evaluated in this study cannot explain this significant decrease in the \%SMHC. Thus, other components of this drink may have a protective effect against dental erosion. The seed powder is rich in caffeine and besides it also contains flavonoids, and tannins. ${ }^{29-32}$ Tannins have been described as having anticariogenic properties. ${ }^{33,34}$ However, there is not any study relating the presence of tan-

Table 2. Mean (SD) surface microhardness of enamel blocks (SMH) before and after (SMH1) cycling and percentage of enamel surface microhardness change (\%SMHC).

\begin{tabular}{lccc}
\hline Groups & Before cycling & After cycling & $\%$ SMHC \\
\hline C & $349.81(19.35)$ & $79.40(15.40)$ & $77.27(4.30)^{\mathrm{ab}}$ \\
$\mathrm{SL}$ & $348.80(19.36)$ & $75.15(17.85)$ & $78.43(5.07)^{\mathrm{b}}$ \\
$\mathrm{CL}$ & $348.64(19.63)$ & $95.63(16.45)$ & $72.45(5.14)^{\mathrm{ac}}$ \\
$\mathrm{P}$ & $348.94(19.67)$ & $111.58(25.00)$ & $67.95(7.14)^{\mathrm{cd}}$ \\
$\mathrm{G}$ & $348.94(20.11)$ & $116.47(30.74)$ & $66.65(8.11)^{\mathrm{d}}$ \\
All Groups & $349.0(19.23)$ & $95.85(27.85)$ & $72.49(7.66)$ \\
\hline
\end{tabular}

Values in the same column followed by distinct lower-case superscript indicate statistical significance $(\mathrm{P}<.05)$

Table 3. Pearson's correlation coefficient for all groups relating the \%SMHC to the variables evaluated.

\begin{tabular}{lcccc}
\hline Variable & Phosphate & Fluoride & Buffer Capacity & $p H$ \\
\hline \multirow{2}{*}{$\%$ SMHC } & $r=0.3399$ & $r=0.7739$ & $r=0.1400$ & $r=-0.8190$ \\
& $P=0.576$ & $P=0.125$ & $P=0.822$ & $P=0.090$ \\
\hline
\end{tabular}


nins in foods and beverages to an effect on dental erosion. The oil extracted from the seeds of Paullinia cupana contains mainly oleic acid $(37.4 \%)$ and cis-11-octadecenoic and cis-11-eicosenoic acids (30.4 and $38.7 \%$, respectively). ${ }^{35}$ These lipids could form a protective layer over the teeth, thus reducing the erosive potential of the drink..$^{36}$ In situ and clinical studies are required to evaluate the erosive potential of Guaraná.

\section{CONCLUSIONS}

The present study showed that the five soft drinks caused surface softening of enamel lerosion). In respect to the chemical characteristics tested, despite not statistically significant, the $\mathrm{pH}$ seems to have more influence on the erosive potential of these drinks. Besides the variables tested, other variables must be taken into account in future studies, such as calcium and lipid contents, especially when developing new soft drinks, aiming at minimizing dental erosion.

\section{REFERENCES}

1. Zipkin J, McClure FJ. Salivary citrate and dental erosion. $J$ Dent Res 1949; 28:613-626.

2. Meurman JH, Frank RM. Progression and surface ultra structure of in vitro caused erosive lesions in human and bovine enamel. Caries Res 1991;25:81-87.

3. Lussi A, Jaeggi T, Zero D. The role of diet in the aetiology of dental erosion. Caries Res 2004;38:34-44.

4. Hunter ML, West NX, Hughes JA. Erosion of deciduous and permanent dental hard tissue in the oral environment. $J$ Dent 2000;28:257-263.

5. Nunn JJ. Prevalence of dental erosion and the implications for oral health. Eur J Oral Sci 1996;104:156-161.

6. Zero DT. Etiology of dental erosion- extrinsic factors. Eur $J$ Oral Sci 1996;104:162-177

7. Behrendt A, Oerste V, Wetzel WE. Fluoride concentration and $\mathrm{pH}$ of iced teas products. Caries Res 2002;36:405-410.

8. Grenby TH, Phillips A, Desai T, Mistry M. Laboratory studies of dental properties of soft drinks. BrJ Nutrit 1989;62: 451-464.

9. Lussi A, Jaeggi T, Schärer S. The influence of different factors on in vitro enamel erosion. Caries Res 1993;27:387393.

10. Fiske $\mathrm{CH}$, Subarrow $\mathrm{Y}$. The colorimetric determination of phosphorus. Biol Chem 1925; 66:375-400.

11. Larsen MJ, Nyvad B. Enamel erosion by some soft drinks and orange juices relative to their $\mathrm{pH}$, buffering effect and contents of calcium phosphate. Caries Res 1999,33:81-87.

12. Featherstone JDB, Rodgers BE. Effect of acetic, lactic and other organic acids on the formation of artificial carious lesions. Caries Res 1981;15:377-385.

13. Bibby BG, Mundorff SA. Enamel demineralization by snack foods. J Dent Res 1975; 54:461-470.

14. Holloway PJ, Mellanby M, Stewart RJC. Fruit drinks and tooth erosion. Br Dent J 1958;104:305-309.

15. Miller CD. Enamel erosion properties of fruits and various beverages. J Am Diet Assoc 1952; 28:319-324.

16. Imfeld TN. Acidogenic and erosive potential of soft drinks and mineral waters; in Meyers HM (ed): Identification of low caries risk dietary components. Monog Oral Sci Base 1983;11:165-174.

17. Stephan RM. Effects of different types of human foods on dental health experimental animals. J Dent Res 1966; 45:151-156.
18. Larsen MJ, Richards A. Fluoride is unable to reduce dental erosion from soft drinks. Caries Res 2002;36:75-80.

19. Meurman JH, Ten Cate JM. Pathogenesis and modifying factors of dental erosion. Eur J Oral Sci 1996;104:199-206.

20. Sorvari R, Meurman JH, Alakuijala P, Frank RM. Effect of fluoride varnish and solution on enamel erosion in vitro. Caries Res 1994;28:227-232.

21. Spencer AJ, Ellis LM. The effect of fluoride and grapefruit on the etching of teeth. J Nutrit 1950;43:107-115.

22. Wiegand A, Attin T. Influence of fluoride on the prevention of erosive lesions - a review. Oral Health Prev Dent 2003; $1: 245-253$

23. Hughes JA, West NX, Parker DM, Newcombe RG, Addy M. Development and evaluation of a low erosive blackcurrant juice drink. 3. Final drink and concentrate, formulae comparisons in situ and overview of the concept. J Dent 1999; 27:345-350.

24. West NX, Hughes JA, Parker DM, Newcombe RG, Addy M. Development and evaluation of a low erosive blackcurrant juice drink. 2. Comparison with a conventional blackcurrant juice drink and orange juice. J Dent 1999;27:341-344.

25. Campos AR, Barros AIS, Santos FA, Rao VSN. Guaraná (Paullinia cupana Mart.) offers protection against gastric lesions induced by ethanol and indomethacin in rats. Phytother Res 2003;17:1199-1202.

26. Erikson HT, Correa MPF, Escobar JR. Guarana (Paullinia cupanal as a commercial crop in Brazil in the Amazon region. Econ Botany 1984;38:273-286.

27. Galduróz JCF, Carlini EA. Acute effects of the Paullinia cupana, guarana, on the congnition of normal volunteers. São Paulo Med J 1994;112:607- 611.

28. Henman AR. Guaraná (Paullinia cupana var-sorbilis): ecological and social perspective on economic plant of the central Amazon Basin. J Ethnopharmacol 1982;6:311-318.

29. Benowitz NL. Clinical pharmacology of caffeine. Ann Rev Pharmacol 1990;41:277-288.

30. Carlson M, Thompson RD. Liquid chromatographic determination of methylxanthines and catechins in herbal preparations containing guarana. J AOAC Int 1998;81:691-701.

31. Loeb H, Vandenplas $Y$, Wursch P, Guersry P. Tannin-rich carob pod for the treatment of acute-onset diarrhea. $J \mathrm{Pe}$ diatr Gastroent 1989;8:480-485.

32. Rice-Evans CA, Miller NJ, Paganga G. Structure-antioxidant activity relationships of flavonoids and phenolic acids. Free Radiol Biolog Med 1996;20:933-956.

33. Kakiuchi N, Hattori M, Nishizawa M, Yamagashi T, OkudaT, Namb C. Studies on dental caries prevention by traditional medicines: Inhibitory effect of various tannis on glucan synthesis glucosyltransferase from Strepcoccus mutans. Chem Pharmacog Bull (Tokyo) 1986;36:720-725.

34. Yanagida A, Kanda T, Tanabe M, Matsudara F, Cordeireo JO. Inhibitory effects of apple polyphenols and related compound cariogenic factors of mutans streptococci. $J$ Agricult Food Chem 2000;48:566-571.

35. Avato P, Pesante MA, Fanizzi FP, Santos CA. Seed oil composition of Paullinia cupana var. sorbilis (Mart.) Ducke. Lipids 2003;38:773-780.

36. Buchalla W, Attin T, Roth P, Hellwig E. Influence of olive oil emulsion on dentine demineralization in vitro. Caries Res 2003;37:100-107. 